\title{
CASES OF ARTERIAL HYPERTENSION IN THE STATE OF AMAPÁ, AMAZON, BRAZIL, BETWEEN 2006 AND 2012
}

\section{ORIGINAL ARTICLE}

FEIO, Stefanie Cecilia Passinho ${ }^{1}$

FECURY, Amanda Alves ${ }^{2}$

OLIVEIRA, Euzébio ${ }^{3}$

DENDASCK, Carla Viana ${ }^{4}$

DIAS, Claudio Alberto Gellis de Mattos ${ }^{5}$

FEIO, Stefanie Cecilia Passinho. Et al. Cases of Arterial Hypertension in the State of Amapá, Amazon, Brazil, between 2006 and 2012. Revista Científica Multidisciplinar Núcleo do Conhecimento. Year 05, Ed. 04, Vol. 04, pp. 105-115. April 2020. ISSN:2448-0959, Access link

in: https://www.nucleodoconhecimento.com.br/health/cases-of-arterial-hypertension, DOI: 10.32749/nucleodoconhecimento.com.br/health/cases-of-arterial-hypertension

\footnotetext{
${ }^{1}$ Mining technician by the Institute of Basic, Technical and Technological Education of Amapá (IFAP).

2 Biomedical, PhD in Topical Diseases, Professor and researcher of the Medicine Course at Campus Macapá, Federal University of Amapá (UNIFAP).

3 Biologist, PhD in Topical Diseases, Professor and researcher of the Physical Education Course at, Federal University of Pará (UFPA).

${ }^{4}$ Theologian, PhD in Psychoanalysis, researcher at the Center for Research and Advanced Studies - CEPA.

${ }^{5}$ Biologist, PhD in Theory and Research of Behavior, Professor and researcher of the Chemistry Degree Course at the Basic, Technical and Technological Institute of Amapá (IFAP).
} 


\section{ABSTRACT}

Arterial hypertension is the abnormal elevation of the pressure that the blood puts on the walls of an individual's blood vessels. The increase in blood pressure occurs quietly so that your symptoms may not be felt at first. The treatment of hypertension can be done through pharmaceutical drugs or through simple actions such as changing daily habits to healthier ones. The purpose of this research is to show the number of cases of hypertension in the state of Amapá between the years 2006 and 2012. The research was carried out in the DATASUS database (http://datasus.saude.gov.br/). The number of cases of hypertension in Amapá in the period from 2006 to 2012 fluctuates considerably between the years, occurring more in the state capital; in women it is greater than in men; in the 50-to-69 age group, the number of cases in other ages is greater than that; and most cases are not influenced by overweight, physical inactivity or smoking. In Amapá, cases of hypertension persist due to the lack of adherence to treatment or incorrect treatment, caused by the lack of information about the severity of the altered pressure for health. Women have greater personal care for their health and greater maintenance of treatment after diagnosis. Chronic non-communicable diseases pose a greater risk to the older age group. The effective cause of hypertension cases in Amapá seems to be the genetic factor and stress, supplanting factors such as overweight and physical inactivity. Reduced schooling leads to job insecurity, increasing stress and altering blood pressure. Smoking is not a major factor because its national reduction was achieved with educational campaigns for young people. Unfortunately, cases of difficult access to health, diagnosis and treatment of hypertensive patients remain real in the interior of the state.

Palavras-chave: Arterial hypertension, Amapá, epidemiology.

\section{INTRODUCTION}

Arterial hypertension is the abnormal elevation of the pressure that the blood puts on the walls of an individual's blood vessels. The standard considered normal is $120 / 80$ $\mathrm{mmHg}$. Values above or far below these are considered abnormal (Micheli and Bitarello, 2008). 
It can be caused by hereditary factors, when the disease gene is passed from father to son, or by factors considered risk factors such as smoking, overweight, physical inactivity, sex, age group and alcoholism (Zaitune et al., 2006).

The increase in blood pressure occurs quietly so that your symptoms may not be felt at first. In many cases, when hypertension is already in more advanced stages, symptoms may eventually be noticed (Monteiro et al., 2005).

There are two types of hypertension: primary (essential) and secondary (nonessential). In the primary type, pressure elevation has unknown causes. This is the most common type among patients. The secondary type of hypertension usually has an identifiable cause. It is caused by temporary factors such as pregnancy, continuous use of medications, or by chronic factors such as kidney disease that cause the patient's pressure to rise. This type corresponds to the minority of cases (Fonseca et al., 2009).

The treatment of hypertension can be done through pharmaceutical drugs or through simple actions such as changing daily habits to healthier ones. Treatment with pharmaceutical drugs is indicated where cases are possibly already affecting the individual in harmful ways or when the increase in pressure is caused by other more serious illnesses. For cases where hypertension is not yet severe or for prevention, the use of natural medications, the practice of physical exercises and care with those considered risk factors are recommended (Zaitune et al., 2006).

Data from the IBGE national health survey conducted in 2013 indicated that $1 / 5$ of the Brazilian population, 31.3 million people, was hypertensive. In the same year, data showed that hypertension in the southern region of the country affected $22.9 \%$ of the population. In the Southeast there were $23.3 \%$ of cases; in the center-west $21.1 \%$; in the northeast 19.4\%; and in the north 14.5\%. In 2013, the state of Amapá had 13.3\% of the population with hypertension (Andrade et al., 2015). 


\section{AIM}

Analyze the percentage of cases of hypertension in the state of Amapá between the years 2006 and 2012.

\section{METHOD}

The research was carried out in the DATASUS database (http://datasus.saude.gov.br/). National data were collected according to the following steps: A) The datasus.gov.br link was accessed, the "access to information" tab was clicked, the "information system (Tabnet)" was clicked, in "Epidemiological and Morbidity". On the open page, "Hypertension and diabetes" went. On the other page, the option "Hiperdia" is selected and in the box "geographic coverage" the state of Amapá was chosen. For each state, the steps were followed: In the line, "Year" was selected, in the "not active" column. and in content, "Hypertension"; "Sex"; "Age Range"; "Overweight"; "Sedentary lifestyle"; "Smoking"; and "Metropolitan Region". For all options in the row above, the field "not active" was used in the column, in the content the field "Hypertension", and in the "available periods" field, data were collected between the years 2006 and 2012. Data compilation was made within the Excel application, part of the Microsoft Corporation Office suite. The bibliographic research was carried out on scientific articles, using computers from the computer lab of the Federal Institute of Education, Science and Technology of Amapá, Campus Macapá, located at: Rodovia BR210 KM 3, s / n - Bairro Brasil Novo. CEP: 68.909-398, Macapá, Amapá, Brazil.

\section{RESULTS}

Figure 1 shows the percentage of hypertension cases in Amapá from 2006 to 2012. The data show that the number of cases fluctuates a lot and its peak was in 2009, where the number of cases increased by $15 \%$ in relation to the previous year. 
Figure 1 Percentage of hypertension cases in the state of Amapá from 2006 to 2012.



Figure 2 shows the percentage of cases of hypertension in the state of Amapá from 2006 to 2012 by gender. The data show that the number of cases in women, in general, is $61 \%$, and men $39 \%$.

Figure 2 Number of cases of hypertension in the state of Amapá from 2006 to 2012 by gender.

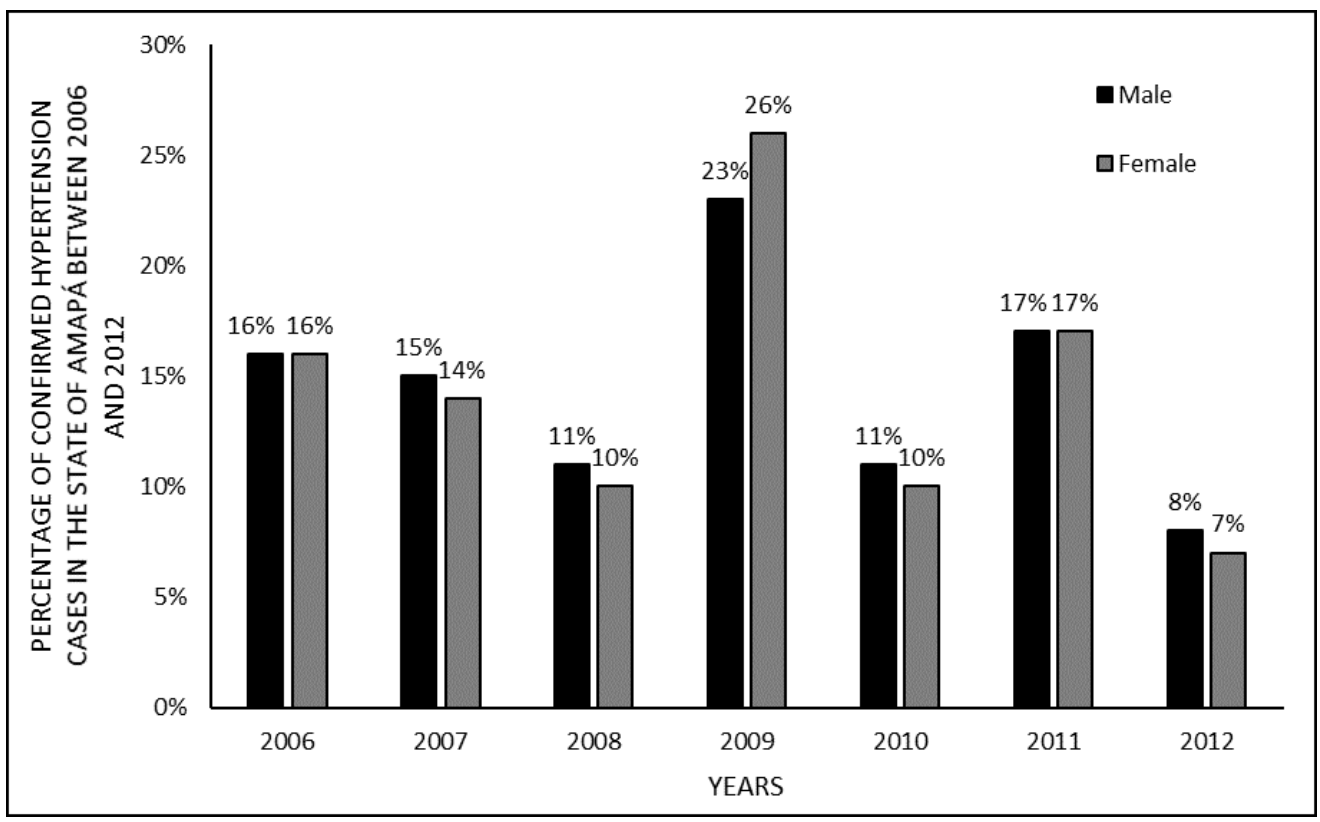

$\mathrm{RC}: 48883$

Disponível em: https://www.nucleodoconhecimento.com.br/health/cases-of-arterial-hypertension 
Figure 3 shows the number of cases of hypertension in the state of Amapá in the period from 2006 to 2012 by age group (age range). The data show that the number of cases in people aged 50 to 69 is greater than the number of cases in other ages

Figure 3 Number of cases of hypertension in the state of Amapá from 2006 to 2012 by age group (age range).

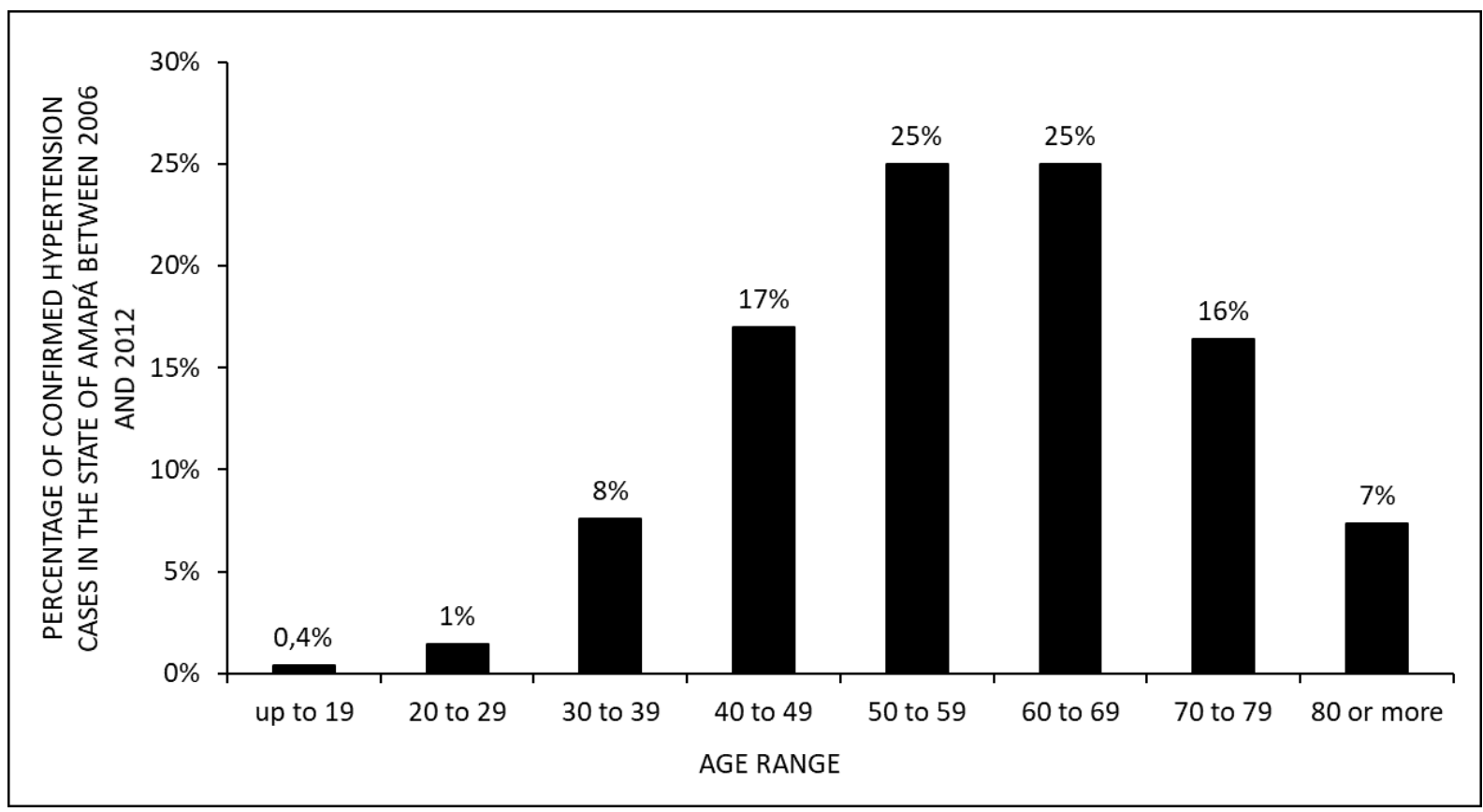

Figure 4 shows the number of cases of hypertension in the state of Amapá from 2006 to 2012 due to overweight. The data show that cases of hypertension caused by overweight are approximately $50 \%$ less than cases of hypertension not caused by overweight. 
Figure 4 Number of hypertension cases in the state of Amapá from 2006 to 2012 due to overweight.

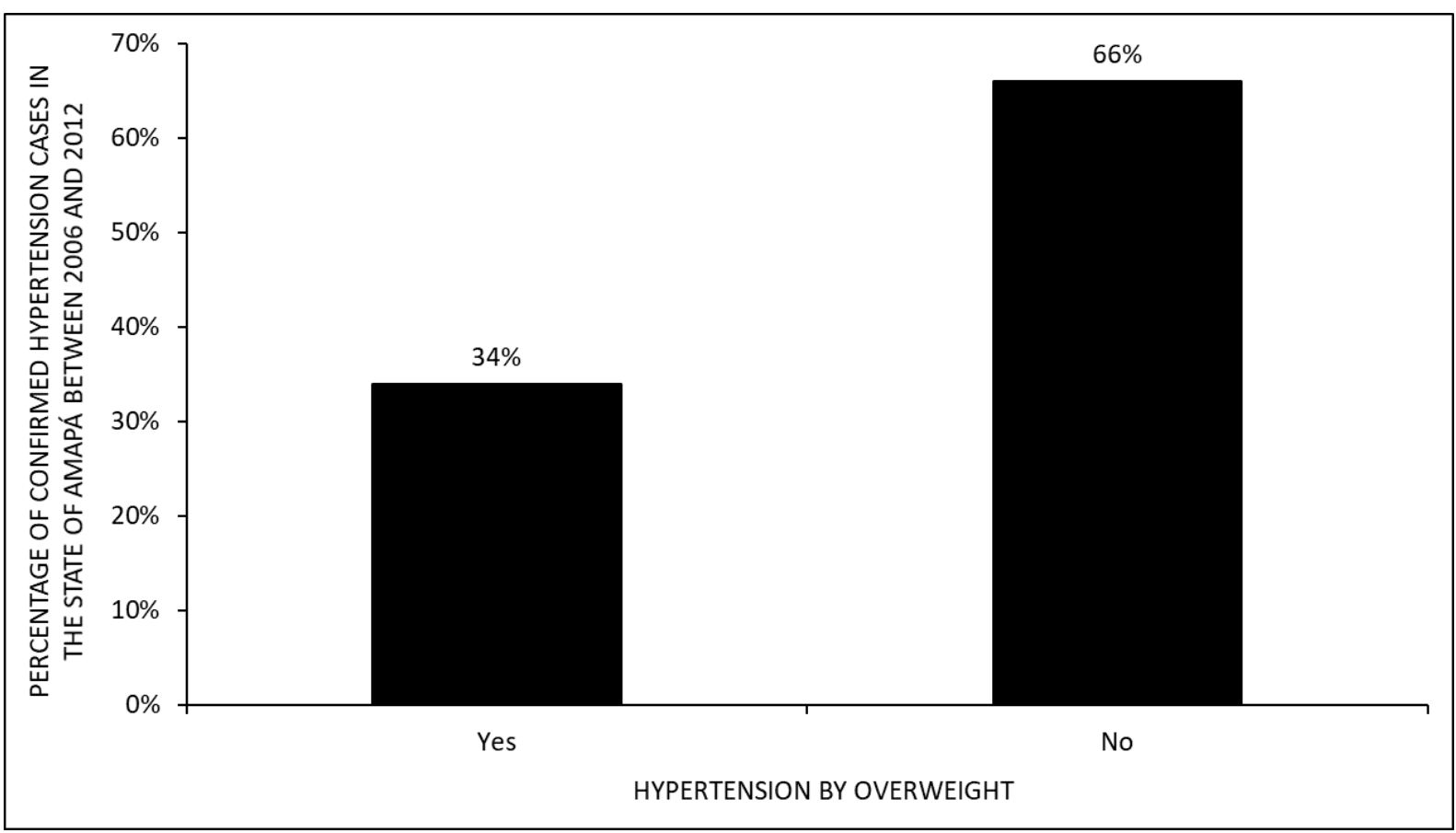

Figure 5 shows the number of cases of hypertension in the state of Amapá from 2006 to 2012 due to physical inactivity (sedentarism). The data show that cases of hypertension caused by sedentary lifestyle correspond to approximately $50 \%$ of cases of hypertension not caused by sedentary lifestyle. 
Figure 5 Number of cases of hypertension in the state of Amapá from 2006 to 2012 due to physical inactivity (sedentarism).

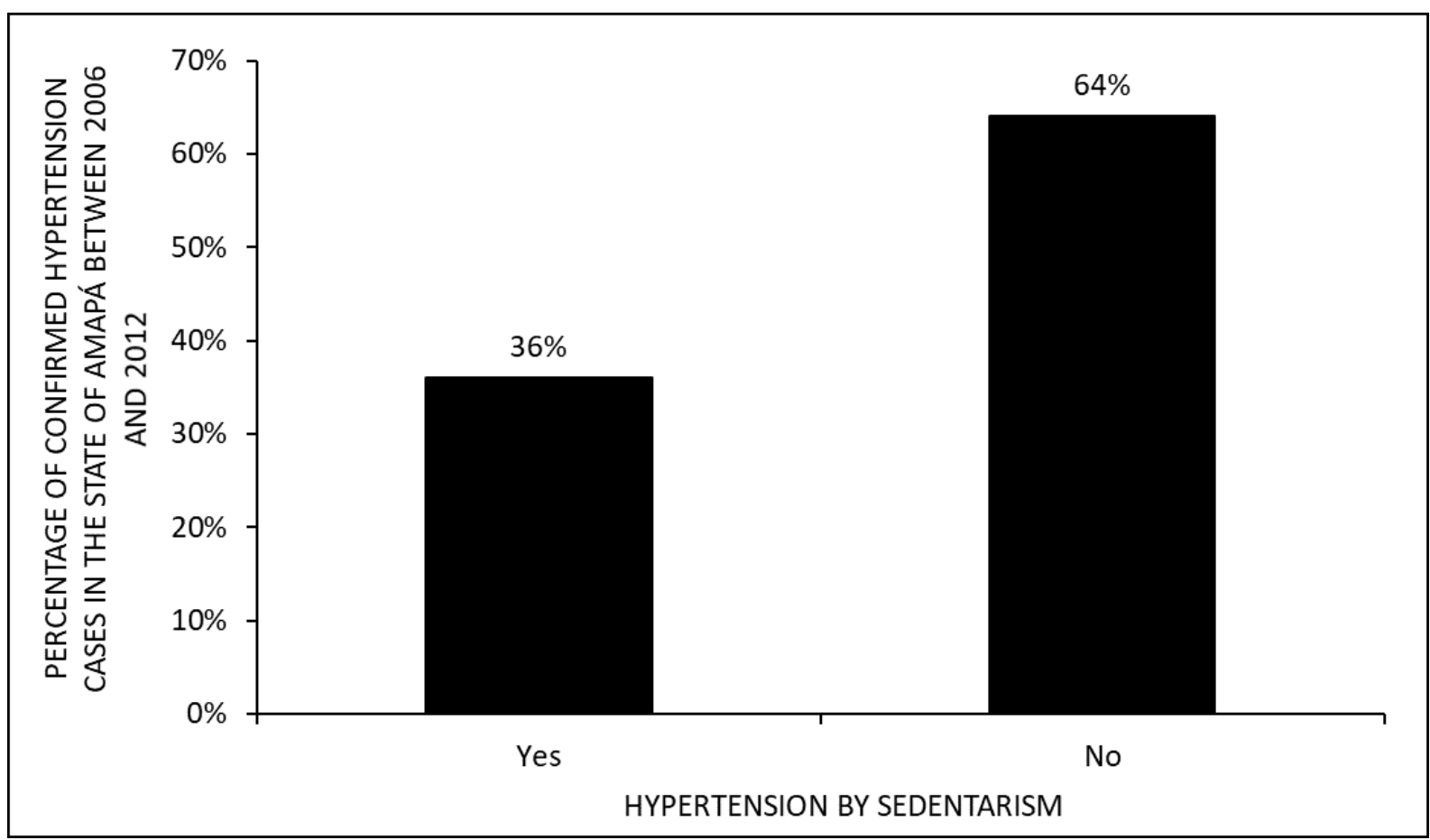

Figure 6 shows the number of cases of hypertension in the state of Amapá from 2006 to 2012 due to smoking. The data show that the number of cases of hypertension caused by smoking is much lower than the number of cases of non-smoking hypertension. 
Figure 6 Number of cases of hypertension in the state of Amapá from 2006 to 2012 due to smoking.

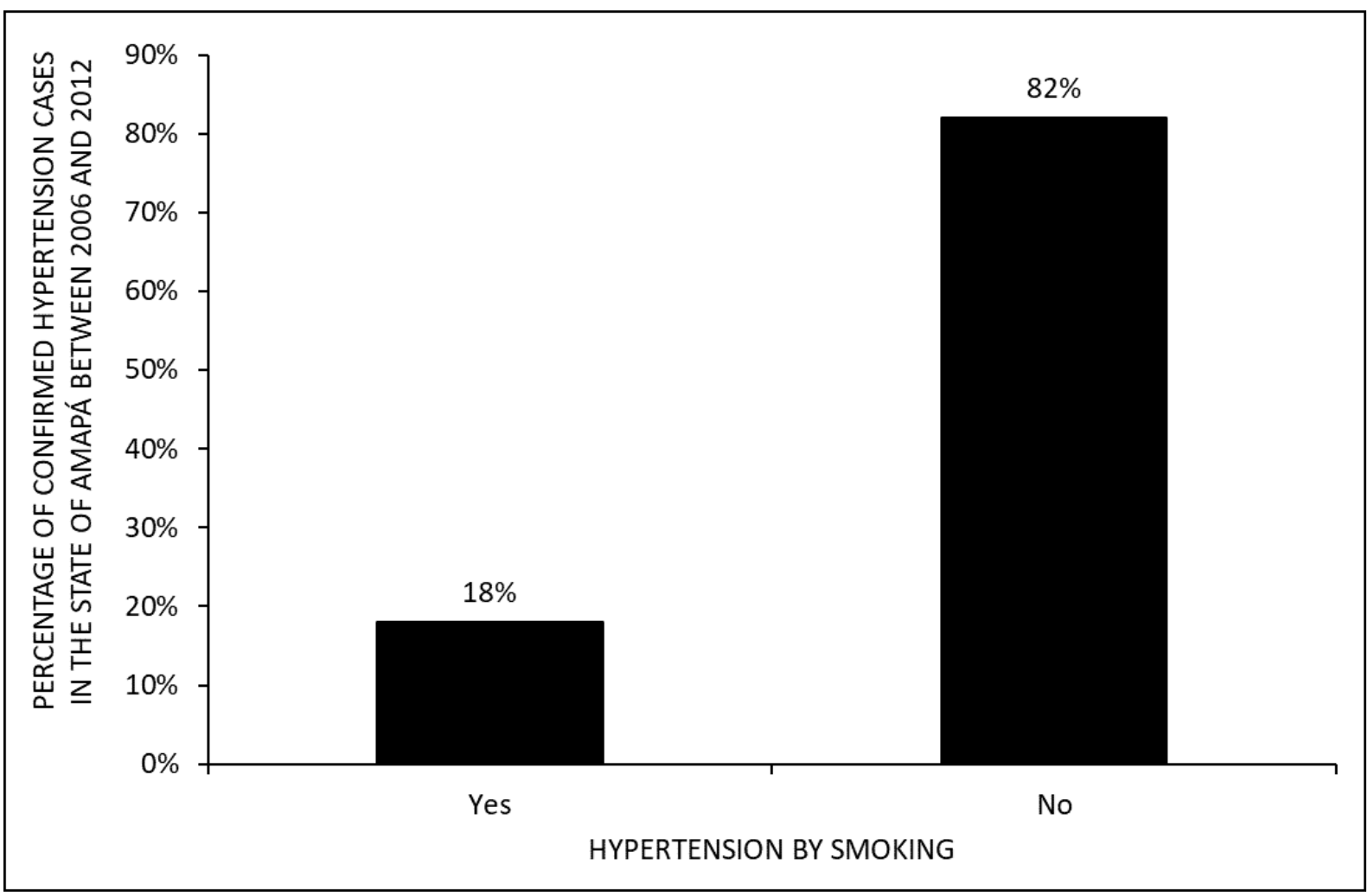

Figure 7 shows the number of cases of hypertension in the state of Amapá from 2006 to 2012 by metropolitan region. The data show that the number of cases in the capital (Macapá) is greater than the number of cases in the interior of the state. 
Figure 7 Number of hypertension cases in the state of Amapá from 2006 to 2012 by metropolitan region.

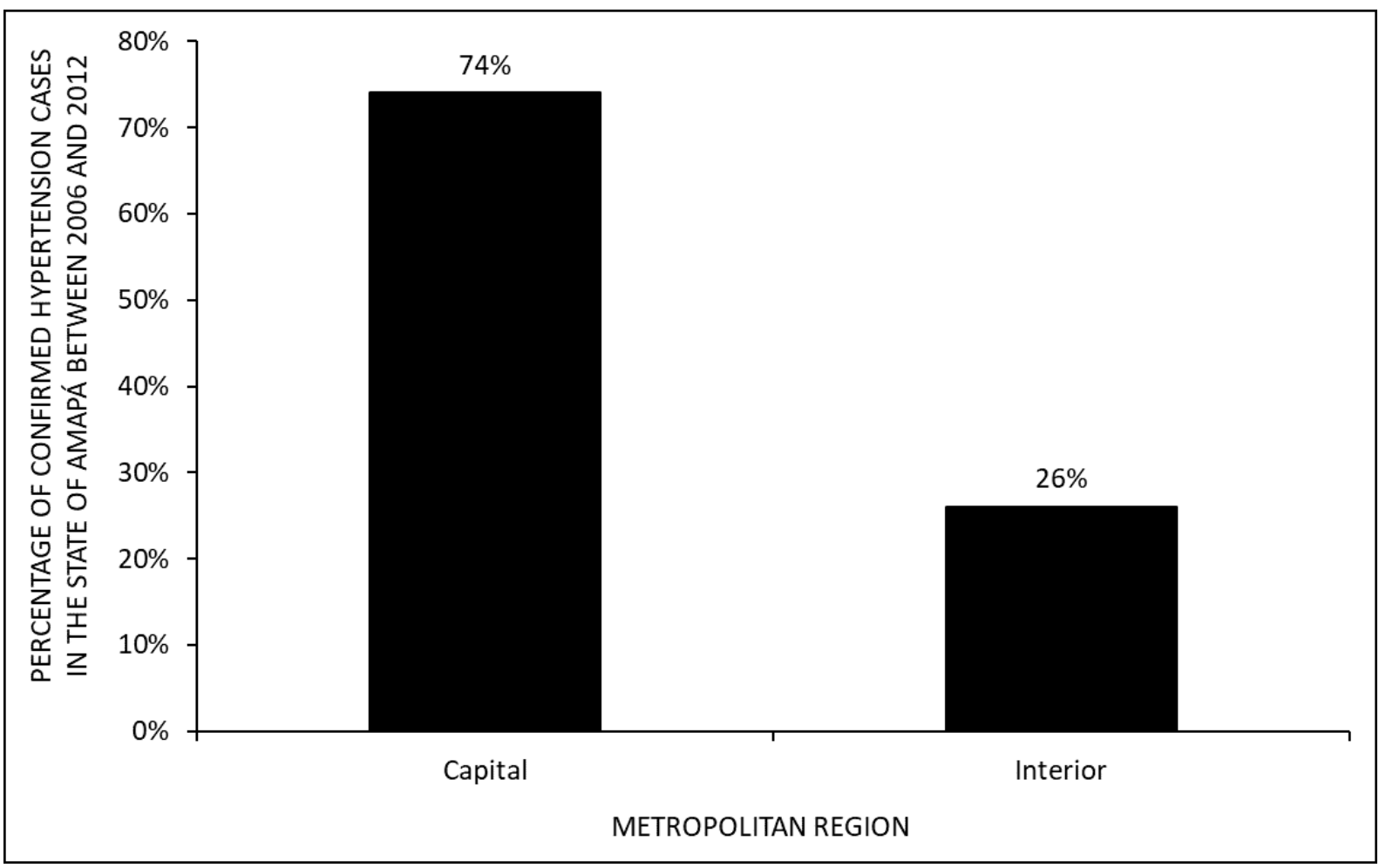

\section{DISCUSSION}

Figure 1 shows the oscillation of hypertension cases in Amapá. The oscillatory number of cases of hypertension may occur due to people not adhering to the treatment correctly or not knowing the real danger of a chronic disease like hypertension. Many abandon treatment because they already think they are cured and then return to the system because they are sick or else they disregard the symptoms and end up not entering the records (Contiero et al., 2009). The biggest drop in 2012 is due to the "Saúde Não Tem Preço" campaign, launched in 2011 by the Brazilian government to distribute free medicines for hypertension, diabetes and asthma (Brazil, 2015).

The data from Amapá is consistent with the literature. The number of cases of hypertension is higher in women (figure 2), probably due to their greater concern with health. They are usually more sensitive to symptoms and usually seek more health facilities and maintain treatment. One of the barriers to the control of hypertension in 
Brazil is the discontinuity and non-adherence of treatment by patients (Santos, 2011; Nogueira et al., 2010).

In Amapá, the number of cases in people aged 50 to 69 years is greater than the number of cases in other ages (figure 3). The number of cases of hypertension in people aged 50 to 69 years is probably higher due to the increase in life expectancy and the elderly population in Brazil. Increasing age increases the risk of developing chronic non-communicable diseases (Mendes et al., 2014).

The data show that the cases of hypertension caused by overweight (figure 4) and hypertension caused by sedentary lifestyle (figure 5) are lower than the cases of hypertension not caused by these two factors. In Amapá, hypertension is primarily caused by genetics, when an individual inherits from a parent a combination of genes predisposed to elevated BP and stress. Because the level of education is low in the state, people end up not being as qualified and without a fixed job they end up being admitted to informal jobs where the workload is large and there is the possibility of dismissal at any time. The anxiety and discontent generated by these reasons can cause increased stress in these individuals causing hypertension (Chagas and Almeida, 2016; Fermino et al., 2009).

The data indicate a smaller number of cases of hypertension related to smoking in Amapá (figure 6). Smoking is a risk factor that corresponds to $18 \%$ of the cases of hypertension in Amapá. This factor is relatively low compared to the others, since the Brazilian government, since the 1990s, has been promoting campaigns to reduce cigarette consumption. The result of this campaign may be the decrease in cases of high blood pressure linked to smoking (Duncan et al., 2012).

The number of cases in the capital is greater than the number of cases in the interior of the state (figure 7). The largest number of cases of hypertension is found in the state capital, probably due to easy access to health facilities. Difficult access makes treatment not only for hypertensive patients but also for patients with other diseases (Brasil et al., 2015). 


\section{CONCLUSION}

In Amapá, cases of hypertension persist due to the lack of adherence to treatment or incorrect treatment, caused by the lack of information about the severity of the altered pressure for health. Women have greater personal care for their health and greater maintenance of treatment after diagnosis. Chronic non-communicable diseases pose a greater risk to the older age group. The effective cause of hypertension cases in Amapá seems to be the genetic factor and stress, supplanting factors such as overweight and physical inactivity. Reduced schooling leads to job insecurity, increasing stress and altering blood pressure. Smoking is not a major factor because its national reduction was achieved with educational campaigns for young people. Unfortunately, cases of difficult access to health, diagnosis and treatment of hypertensive patients remain real in the interior of the state.

\section{REFERENCES}

ANDRADE, S.S.A.; STOPA, S.R.; BRITO, A.S.; CHUERI, P.S.; SZWARCWALD, C.L.; MALTA, D.C. Prevalência de hipertensão arterial autorreferida na população brasileira: análise da Pesquisa Nacional de Saúde, 2013. Epidemiol. Serv. Saúde, Brasília, v. 24, n.2, 297-304, 2015.

BRASIL. Hipertensão atinge mais de 30 milhões de pessoas no País. Disponível em: <http://www.brasil.gov.br/saude/2015/04/hipertensao-atinge-mais-de-30-milhoes-depessoas-no-pais> Acesso em: 21 de Setembro de 2017.

CONTIERO, A. P.; POZATI, M. P. S.; CHALLOUTS, R. I.; CARREIRA, L.; MARCON, S. S. Idoso com hipertensão arterial: dificuldades de acompanhamento na Estratégia Saúde da Família. Rev Gaúcha Enferm., V. 30,N. 1, 62-70, 2009.

CHAGAS, J. A. S.; ALMEIDA, A. N. F. Caracterização epidemiológica de pacientes hipertensos usuários de uma unidade básica de saúde da região Norte. Estação Científica (UNIFAP) Macapá, v. 6, n. 2, p. 105-116, maio/ago. 2016. 
DUNCAN, B.B.; CHOR, D.; AQUINO, E. M. L.; BENSENOR, I. M; MILL, J. G.; SCHMIDT, M. I.; LOTUFO, P. A.; VIGO, A.; BARRETO, S. M. Doenças crônicas não Transmissíveis no Brasil: Prioridade para enfrentamento e investigação. Rev. Saúde Pública, v. 46, 126-34 2012.

FERMINO, R. C.; SEABRA, A.; GARGANTA, R.; MAIA, J. A. R. Fatores genéticos e variabilidade na pressão arterial. Uma breve revisão da literatura. Rev Bras Cineantropom Desempenho Hum, v.11, n.3, 341-349, 2009.

FONSECA, F.C.A.; COELHO, R.Z.; NICOLATO, R.; MALLOY-DINZ, L.F.; FILHO, H.C.S. A influência de fatores emocionais sobre a hipertensão arterial. J Bras Psiquiatr., v. 58, n.2, 128-134, 2009.

MENDES, G. S.; MORAES, C. F.; GOMES, L. Prevalência de hipertensão arterial sistêmica em idosos no Brasil entre 2006 e 2010. Rev. Bras Med. Fam. Comunidade, v. 9, n. 32, 273-278, 2014.

MICHELI, T.; BITARELLO, D.A. O enfermeiro, na atenção básica, ao lidar com hipertensão como fator de risco para insuficiência renal crônica. Revista de Iniciação Científica da FFC, v. 8, n.3, 329-337, 2008.

MONTEIRO, P.C.; SANTOS, F.S.; FORNAZARI, P.A.; CESARINO, C.B. Características biossociais, hábitos de vida e controle da pressão arterial dos pacientes em um programa de hipertensão. Arq. Ciênc. Saúde, v.12, n.2, 73-9, 2005 NOGUEIRA D.; FAERSTEIN E.; COELI C. M.; CHOR D.; LOPES C. S.; WERNECK G. L. Reconhecimento, tratamento e controle da hipertensão arterial: Estudo PróSaúde, Brasil. Rev. Panam Salud Publica, v. 27, n. 2,103-9, 2010.

SANTOS, Z. M. S. A. Hipertensão arterial - Um problema de saúde pública. Rev. Bras Promoç Saúde, v. 24, n. 4, 285-286, 2011.

ZAITUNE, M.P.A.; BARROS, M.B.A.; CÉZAR, C.L.G.; GARANDINA, L.; GOLDBAUM, M. Hipertensão arterial em idosos: prevalência, fatores associados e práticas de 
controle no Município de Campinas, São Paulo, Brasil. Cad. Saúde Pública, Rio de Janeiro, v.22, n.2, 285-294, 2006.

Submitted: April, 2020.

Approved: April, 2020. 